\title{
PROBLEMATIKA TALFIQ MAZHAB DALAM PENEMUAN HUKUM ISLAM
}

\author{
Fauzi Saleh*
}

\begin{abstract}
A bstract: It has been commonlyargued that theIdamiclawisardaineeltoaddressandpresere theinterest of $m$. Thenles and values of Isamiclaware therfore in accordance vith the natureof humanbing And becausetheIdamiclawisreveledfor all season, asit wee, itmst accordingybedeqdyflexidesothat it may fit toall timeandall space Thispaper addressesthis notion of flexibility that Isamiclawenjoys byarging that flexibilityisa quality that Isamic lawshould haveifit istosurvive But, it moves on, that flexibilityis onethingand theability of Musimschdars in presering this flexibility is somthing dse Whileby its very nature, Isamiclawisflexildethem thoods andapproadhes that someMusimschdarshavedadqpeed did work on thenerveof thisdivinelaw Oneof summthodistalfic inwhichonewould takethe viens of different shdars toprodurea legal dictum Thismthod is thefous of this paper. It contends that in priniple, them thodis a result of theabsene of theindqpendent mindin the historyof Isam It nonthdess, dbesseveasagoodm thod toprodurealegal premises suitable for cetaintype of Musimsoidy. But it dbes not al ways work topresevetheflexibilityof the Isamiclaw

Keywords: talfick mazhab themthodbloy of Isamiclaw
\end{abstract}

\section{Pendahuluan}

Talfię merupakan konsep yang baru dikenal pada masa dan pasca mazhab. Meskipun demikian, konsep ini justru yang lebih masyhur dibandingkan dengan mazhab itu sendiri. Problematika talfiq antara yang membolehkan dan menolak telah membuat keresahan di tengah masyarakat terutama kaum aumamyang tingkat pemahaman keagamaan hukum Islam sangat minim. Ambigiutas tersebut pada tataran tertentu melemahkan motivasi umat untuk beramal dan berkreasi. Sedangkan bagi ilmuwan menganggap tadid itu pada titik tertentu sama dengan menutup pinta ijtihad karena beranggapan usaha imam mazhab diangap sudah memadai untuk menjawab semua persoalan umat. Lebih ekstrim lagi, setiap mazhab memiliki 'konstituen' yang masing-masing tidak boleh pindah ke mazhab yang lain.

Problematika talfieq dan kerancuan dapat dicontohkan sebagai berikut: seseorang yang bermazhab Shafi'i berwudhu' lalu menyentuh isterinya maka wudhu'nya sudah batal menurut mazhab yang diikutinya, sementara hadith shahih menjelaskan bahwa Rasulullah saw menyentuh bahkan mencium isterinya sebelum sł̣lat dan tidak berwudhu' lagi. Karena itu, mazhab Hanafi menganggap bahwa menyentuh isteri itu tidak membatalkan wudhu'

$\bar{*}$ Institut Agama Islam Negeri (IAIN) Ar-Raniry Banda Aceh

${ }^{1}$ Talfiqsecara harfiah berarti menyamakan atau merapatkan dua ujung barang yang berbeda, atau menambahkan sesuatu yang digunakan untuk suatu berita atau cerita. Secara terminologi fiqih adalah sebagai berikut.

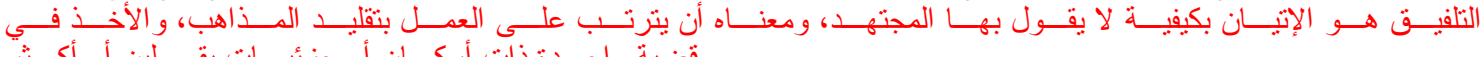

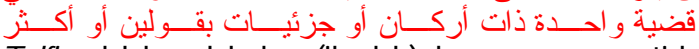

Talfiqadalah melakukan (ibadah) dengan cara yang tidak disebutkan mujtahid. Maknanya beramal dengan mengikuti beberapa mazhab, dan mengambil suatu permasalahan yang memiliki rukun (pilar) atau parsialnya dari dua pendapat atau lebih. Atau dalam redaksi lain, talfiqyakni cara mengamalkan suatu ajaran agama dengan mengikuti secara taqlidberbagai mazhab sehingga satu amalan terdapat pendapat berbagai mazhab. Lihat al-Zuhayli, FiqhalIsami naAdillatuh(K airo, D aæal-Fikr, t.th), 1142; Abdul Aziz D ahlan, Ensiklqpedi HukumIsam(Jakarta: Ichtiar Baru van Hove, 1997), 1786; Azyumardi Azra dkk, Ensikopedi Islam (Jakarta: Ichtiar Baru, 2005), 68. 
atas dasar hadith tersebut. Permasalahan di sini adalah haruskah dia konsisten dengan mazhab yang dianutnya yang menyatakan kebatalan wudhu' karena bersentuhan dengan isteri tanpa penghalang atau boleh ia bertalfiq kepada mazhab Hanafi karena menurutnya dalil yang menjadi landasan mazhab yang bersangkutan lebih kuat atau langsung kembali ke hadith tanpa harus perantaraan mazhab umpamanya. Secara metodologis, dalil (baca: al-Q ur'an dan Hadith) sainh dapat mengalahkan pendapat mazhab yang merupakan pemahamana dari dalil. Namun pada realitanya, banyak orang yang meninggalkan hadith lantaran bertentangan dengan pendapat mazhab. Hal-hal semacam ini justeru ambigiutas pemahaman dan pengamalan terhadap hukum yang kemudian munculnya silang pendapat yang sangat signifikan antara kelompok mainstreamya mempertahankan mazhab dan menolak talfiq dan kelompok moderat yang membolehkan talfieq tanpa harus di-'keengkeng' dengan pendapat mazhab.

\section{Terma Talfiq Menarik Diulas}

Adapun hal yang menarik dalam kaitannya dengan talfiq- seiring dengan perkembangan pengetahuan terutama tentang metodologi hukum Islam di antaranya adalah: petama, belum adanya sebuah definisi baku terhadap talfie itu sendiri sehingga orang ketika membolehkan dan melarang melakukan talfiø perlu dikejar dengan pertanyaan: definisi talfiø mana yang dimaksud.

Kedua, talfiqmerupakan tergolong 'barang' baru muncul setelah lebih kurang empat ratus tahun setelah Nabi saw wafat. Artinya para sahabat dan tabi'in sudah pasti tidak familiar dengan talfiq yang dimaksud oleh ulama mazhab mitaakhkhinin Tapi kemudian ia menjadi terma yang sangat kaku dan baku dengan segala konsekuensinya. Peneliti berhipotesa bahwa para ulama terdahulu memakai sadd al-dhari'gh untuk menutup kemungkinan adanya kemungkinan sebagian umat yang melakukan tatabbu' nukhas\}(mencari yang mudah-mudah) dari sejumlah mazhab untuk diamalkan. Istilah talfiq- menurut hipotesa peneliti - kemudian menjadi metode 'haram' diaplikasikan dalam pengamalalan ibadah. Kemungkinan yang lain adalah adanya konsolidasi internal mazhab dengan segala pengikutnya. Ada usaha-usaha dari tokoh mazhabi untuk mengikat umat pada mazhab tertentu, meskipun hal tersebut berlawanan dengan keinginan imam mazhabnya. Hal tersebut terbukti ada sebagian yang menjelekkan mazhab yang lain dengan ucapan atau tulisan vulgar.

D engan kata lain, pemahaman talfiq secara konseptual dan operasional perlu adanya badhl al-juhd (usaha maksimal) sehingga dapat dirumuskan dengan baik dalam kerangka ontologis, epistemologis maupun aksiologisnya. Ketiga, talfiø itu - sebagaimana pula dipertanyakan Abdul G hani al-Nabulsi dalam kitabnya Khulasat al-Tahłiiq fi Bayan HxikmalTaqlid na al-Talfiq́. - apakah berlaku untuk semua orang atau hanya diperuntukkan kepada mittabi' (pengikut yang mengikuti landasan amaliyahnya) dan muqallid (pengikut tanpa mengetahui landasan amalan yang dikerjakan), tidak indude di dalamnya mijtahid

D ari aspek aksiologis, bila penelitian dapat diselesaikan dengan baik maka akan -petama- memberikan kontribusi penting dalam kontruksi metodologi hukum. Kedua, umat Islam dapat memosisikan dirinya dengan baik dalam pro-kontra talfiq yang sekarang ini

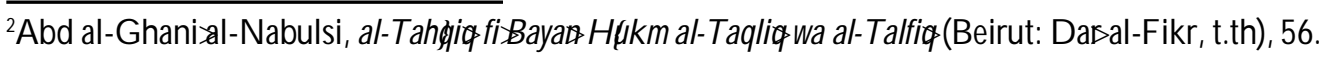


terjadi. Ketiga, proyeksi ke depan terutama dalam pengembangan ïjihadiyah baru terhadap problematika sosial kemasyarakatan adalah terbangun semangat mijtahidkontemporer dalam menelaah dan mengistinbat/ hukum baik dengan eklektisisme mazhabi, multi dan interdisdicipliner approadh sebagai pendekatan-pendekatan yang menarik.

Istilah talfiqitu diduga muncul sebagai antitesis terhadap kuatnya mainstreammazhabi yang tertanam dan mengakar dalam amaliyah keagamaan. 'Tokoh-tokoh' mazhab kebanyakan mengharamkan prilaku talfiøqdengan berbagai alasan, di antaranya mereka berargumen bahwa talfiqgdapat mendorong seseorang untuk berhilahdemi menggapai interestpribadi yang berujung pada menghalalkan yang haram dan mengharamkan yang halal.

\section{Talfiq, Mazhab dan Metodologi Hukum Islam}

Talfiqadalah cara mengamalkan suatu ajaran agama dengan mengikuti berbagai mazhab secara taqidissehingga satu amalan ibadah yang dikerjakan itu didasarkan pada akumulasi pendapat dari berbagai mazhab

Mazhabadalah sebuah metodologi fiqih khsus yang dijalani oleh ahli fiqih (mujtahid), yang berbeda dengan ahli fiqih yang lain, yang menghantarkannya memilih sejumlah hukum dalam kawasan ilmu funơ D ari kalangan Sunni, mazhab ini terdiri dari Hanafi, Maliki, Shafi' 'i, dan Hanbali. Sementara dari golongan Shi $>>$ mazhab terdiri dari Ja 'fariyah, Ismailiyah`dan Zaidiyyah. $^{3}$

Metodologi Hukum Islam adalah ilmu tentang kaidah-kaidah umum yang dapat digunakan untuk melakukan istinbatthukum-hukum shar'i \dari dalil-dalilnya yang terperinci. Metodologi yang dimaksud di sini sinonim dengan Usłlibal- Fiqh

\section{Silang Pendapat tentang Talfiq}

Menurut Muhammad Abu Zahrah (w. 1394 H/ 1974 M), konsep talfiqmuncul akibat kuatnya perasaan taqlid yang ditanamkan ulama mazhab di zaman berkembangnya taqlid yang mengharamkan seorang pengikut mazhab tertentu untuk mengambil pendapat dari mazhab lain. Menurutnya, ulama fiqih dan Usł⿺ al-Fiqh yang tidak membolehkan talfiq dalam beramal jumlahnya amat sedikit, di antaranya Abu Bakar al-Q affal (291-365 H), Ibn Hajar al-'Asqalani, keduanya ulama fiqih Mazhab Shafi'i dan sebagian mazhab Hanafi'.

Ulama - semacam al-Safarini sebagai didukung oleh al-G hazali dan al-Marudzi - tidak membolehkan talfiø dengan alasan, petama: seandainya dibukakan pintu talfiømaka rusaklah sharisah dan terbuka kesempatan untuk membolehkan hal-hal yang haram, termasuk pembolehan perbuatan zina, minuman keras dan seterusnya. Hal tersebut diumpamakan bahwa orang yang hendak berzina dengan perempuan yang baligh 'aqil dengan beralasan ikut Abu Hanifah yang berpendapat kesahihan perempuan untuk melakukan akad terhadap dirinya sendiri. Abu Hanifah tidak mensyaratkan wali lalu mengambil pendapat Malikiyah yang tidak mensyaratkan saksi dalam pernikahan. D engan cara seperti ini berarti ia sudah mencari jalan untuk melegalkan perzinahan ${ }^{5}$

${ }^{3}$ al-Asyqar, t.th: 5 .

${ }^{4}$ D ahlan, Ensiklopedi HukumIdaml1997: 1786.

${ }^{5}$ Muhammad bin A hmad al-Saffarini, al-TahłiqButlanal-Talfic(Mesir: D azal-Sami',1998), 171-177) ${ }^{6}$ Al-G hazali menyebutkan bahwa meskipun keterkaitan dengan mazhab tertentu tidak diwajibkan dari awal, namun ketika 
Keeua, kaidah usul:

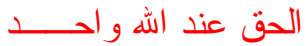

Maka apabila seseorang mengikuti seorang imam dengan mazhabnya, maka yang bersangkutan yakin bahwa ucapan imam itu benar. Sedangkan pendapat lain yang berbeda dengan mazhab yang dipeganginya memiliki multi-nilai, mungkin benar atau mungkin salah. Jadi talficitu membangun paradigma bahwa setiap mujtahid itu benar dan jelas hal ini bertolak belakang dengan kaidah. Ketiga, mereka berargumen bahwa tidak ada dalil shariłah yang membolehkan talfic ${ }^{6}$

Sebagian ulama tidak membolehkan talfiq dengan alasan tatabbu' al-yusr (mencari-cari kemudahan) atau taysir al-fatwa> Taysir al-fatwa ${ }^{\Upsilon}$ yang dimaksud adalah memberikan fatwa terhadap seseorang yang di dalamnya terhadap pilihan-pilihan yang Shara' membolehkannya sesuai dengan kondisi mikallaf ${ }^{8}$.

D alam konteks ini dapat dicontohkan seumpama orang bertanya kepada seorang 'alim tentang menyapu kepala sebagai bagian rukun wudhu'. Maka sang 'alim memberikan jawaban berdasarkan mazhab Shafi'i yakni wajib membasuhnya sebagian kepala saja, kemudian ditanya masalah menyentuh zakar tanpa kain. Maka si 'alim memberikan jawaban bersandarkan kepada mazhab Abu Hanifah.

Sementara pihak lain melakukan antitesis terhadap argumentasi sebelumnya. Petama, pendapat sebelumnya mengatakan bahwa talfiq ini hanya memberikan kemudahan ${ }^{9}$ bagi mukallaf, namun perlu diingat bahwa kemudahan dalam shariłat yang mu'tabar memang didukung oleh dalil baik yang khusus atau umum. Kedua, meskipun secara umum talfiq cenderung menghasilkan kemudahan dalam pengamalan shariat tapi kadang pula menghasilkan produk hukum yang berat. Contohnya: larangan melempar jamarah pada malam hari didasarkan pada pendapat Imam Ahmad, dan mengharuskan bayar dam(denda) bagi orang memotong rambut sebelum melempar jamarah itu didasarkan pada pendapat Imam Malik $^{10}$

Ketiga, larangan talfiq tidak disebutkan dalam al-Q ur'an dan al-Sunnah ataupun Qawk al-Słahdhi-Sahabat sendiri tidak terikat dengan pendapat orang lain, bahkan mereka memiliki independensi dalam mengeluarkan pendapat dalam memahami nas\$.." ${ }^{11}$

Sebagian usllikyum dan fuqaha membolehkan talfiq karena darurat dengan alasan

seseorang bermazhab dengan imam tertentu, maka ia tidak boleh menyalahinya. Lihat al-G hazali, al-Mustashamin Tlmal-Usłbl,jilid IV (Madinah: Shirkat al-Munawwarah li al-Ti ibb wa al-Nashr, t.th), 154.

${ }^{6}$ al-Saffarini, al-Tahłiq 175.

${ }^{7}$ Fatwa adalah memberikan keteragan hukum Shar'i bagi orang yang bertanya. Amir bin Said al-Zaybari, Mabakith fi A kkamal-FatvałBeirut: D as Ibn Hazm, 1995), 32.

${ }^{8} \mathrm{G}$ haziłłin Mursyid, Talfiçbaynal-Madhakibal-Fiqhiłahna 'Alaqahli Taysiral-FatwałMakkah: Jami' Umm al-Qura> Press, 2009), 35.

${ }^{9}$ Hukum Shar' dilihat dari sisi mudah-payahnya dapat dibagi menjadi: petama, hukum yang ditetapkan dengan kemudahan sejak awal seumpama hukum tharah syarat dan rukun ibadah, hukum jual beli dan sewa menyewa, makan minum dan seterusnya. Kedua, hukum yang ditetapkan dengan shiddah (penuh kesulitan) sejak awal seumpama pengharaman riba, zina dan makan bangkai. Ketiga, hukum yang ditetapkan dengan kesulitan lalu dinasakh (dihapuskan) setelah itu seumpama kewajiban melawan musuh dengan bandingan 1:10 dan dinasakh menjadi 1:2, hukum menunggu bagi isteri yang ditinggal suami mati dari setahun dinasakhmenjadi empat bulan

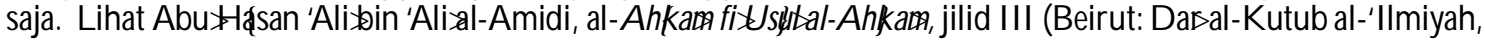
t.th), 135.

${ }^{10}$ MuhAmmad bin Rushd al-Q urthbi>Bidayat al-Mujtahid jilid I (Beirut: D aral-Ma'rifah, t.th), 352.

${ }^{11}$ Muhæmmad Sa'id al-Bani, Ummatutal-Tahdiqfi al-Taqlidwaal-Talfic(Beirut: al-Maktab al-Islami>1981), 98-110. 
memberikan keringangan kepada si mukallaf. Pendapat tersebut didukung oleh Albani. ${ }^{12}$ Menurut al-Bani, orang yang paling berhak diberikan toleransi dalam hal ibah termasuk talfiq adalah mereka yang dáii karena penyakit, pekerja berat, tentara, mereka terpaksa, yang kecil daya nalar dan pengetahuan agama ${ }^{13}$

Syeikh Mar'i al-Karami - sebagaimana dikutip oleh Ghazi ibn Mursyid - memiliki sikap yang sangat tegas terkait dengan talfiq Ia berpendapat bahwa talfiq adalah keniscayaan apalagi bagi orang 'awam untuk melakukan talfiø. K alau tidak - menurutnya - mengakibatkan ketidakvalidan ibadah dan muamalah mereka dan lebih jauh lagi akan berdampak pada kesempitan dan kesulitan yang jelas bertentangan dengan macasid al-shar'łh yang dibangun atas dasar atas kemudahan dan keringanan. ${ }^{14}$

Ulama yang membolehkan talfiq seumpama Imam Kamal bin Hummam (w $861 \mathrm{H}$ / 1458 M), Ibn Nujaim (w.970 H/ 1563 M), keduanya ulama fiqih Mazhab Hanfi, al-Q arafi (w. 684 H/ 1285 M) dan Ibn Urfah al-Wargami al-Tunisi atau Ibn 'Urfah al-Maliki (w. 803 H/ 1400 M), keduanya ulama fiqih Mazhab Maliki dan sebagian besar ulama mazhab Shafí 'i. ${ }^{15}$

\section{Mencari Jalan Menyelesaikan Persoalan}

Al-Q aradhawi - dalam konteks penyebab utama timbulnya talfiq - menyebutkan problematika ketergantungan kepada mazhab tertentu kadang-kadang menyebabkan seseorang berpikiran sempit dan kaku dalam melihat kasus-kasus yang silih berganti ${ }^{16}$.

Dari persoalan yang ada kemudian timbul pula pertanyaan apa hukum bermazhab itu? Seorang muslim yang hendak mengamalkan ajaran Islam yang benar umpamanya, haruskah mengikuti mazhab tertentu atau dia memiliki pilihan antara mazhab mana saja yang dia sukai dengan kriteria tertentu atau paling ekstrim bolehkah kalau dia tidak bermazhab?

Bagi ulama semacam Ibn al-Subki, Zakariya al-Ansari dan beberapa lainnya akan berpendapat bahwa bermazhab itu hukumnya wajib. Bahkan sebagian pengikut Hanafiyah pada masa belakangan berpendapat lebih ekstrim yakni pengikut mazhab Hanafi apabila berpindah ke mazhab al-Shafi'i 'maka harus dita'zir, karena mereka berpendapat bahwa pengikut suatu mazhab berpegang pada mazhab yang dipeganginya sebagai suatu pendapat yang paling benar menurut złamya, karenanya tidak boleh meninggalkan mazhab yang dianut ${ }^{17}$.

Pendapat ini jelas menunjukkan betapa mainstreammezhab itu sangat kuat dan paling klimaksnya berujung pada truth daim dan menafikan mazhab lainnya. Hal itu sangat memungkinkan untuk menafikan talfiq mazhab, karena talfiq itu akan berujung kepada penafian konsideran mazhab dalam melihat suatu persoalan hukum Islam.

Lainnya halnya dengan ulama seperti Ibn al-Hajib, al-Nawawi, Ibn Taimiyah dan Ibn

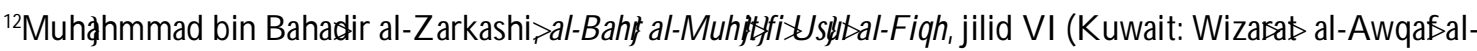
Quwaytiyah, 1992), 323.

${ }^{13}$ Al-Bani> Umdatal-Tahdiq 130-131.

${ }^{14} \mathrm{G}$ haziłoin Murshid, Talfieqbaynal-Madhakib, 39.

${ }^{15}$ Abdul Aziz D ahlan, Ennsklopedia HukumIsam 1786.

${ }^{16}$ Y usuf al-Q ardł̧wi>Taysizal-Fiqhli al-Musimal-Múasir(Mesir: Maktabah Wahbah, 1999), 35.

${ }^{17}$ Muhłmmad Buhayt al-Muti'i> Sullamal-Wsłkl li ShamhNihayatal-Sjal, jilid IV (Beirut: 'Alam al-Kutub, t.th), 618.

${ }^{18}$ Ibn Taimiyyah, 1991: 222-223; Ibn Q ayyim, t.th.: 261.
} 
Q ayyim. Mereka berpendapat bahwa bermazhab itu tidak wajib. Argumentasinya adalah tidak ada kewajiban kecuali apa yang diwajibkan Allah swt. dan Rasul-Nya saw. D alam konteks ini, Allah swt. dan Rasul-Nya tidak pernah mewajibkan untuk bermazhab dengan imam tertentu ${ }^{18}$.

Pendapat lain dari diskurus ini adalah mazhab yang wajib diikuti dalam hal-hal yang menyangkut kemasyarakatan adalah mazhab pemerintah atau pendapat yang diundangkan pemerintah lewat perundang-undangan. $\mathrm{Hal}$ ini dimaksudkan untuk keseragaman dan menghindarkan adanya kesimpang-siuran. Hal ini sejalan dengan kaidah, "Keputusan pemerintah mengikat atau wajib dipatuhi dan akan menyelesaikan persengketaan ${ }^{19}$.

Ilmuwan merespon problematika umat yang terus bertambah dengan upgrading metodologi hukum Islam dan termasuk bagaimana menyikapi permasalahan talfieq ini. Butti umpamanya mengungkapkan:

Islamicmodemists proposed threecomplemetary methods of dleialinghardshipthraghtakhayyur and talfie, reinterpreting shariah texts and the dotrine of siyasa syar'iyyah ${ }^{20}$.

Tdkdh modemis mengusulkan tiga mtodekomplementer untuk mengilangkan masyaquah midalui pintu takhayyur dan talfieq penefsiran kenbali tdks syariah dan ddktin siyasah syar'iyyah

\section{Birgit Krawidz, di sisi lain mendeatkan:}

In addition to talfie, there are other strategies to overcmetherigity of tadlid, the unquestioning of adherence to one of athoobx schods of law"

Di samping talfic ada strategi-strategi lain untuk mengatasi rigiditas taqlid hal-hal yang tidak dapat dipertanyakan terhadap mazhab-mazhab ortodok dalam Islam.

Hukum Islam (baca: Fiqih) idealnya harus mampu memberikan kenyamanan dan kepastian normatif dalam melaksanakan titah Allah swt. Artinya Fuqaha memiliki otoritas untuk berijtihad untuk menghasilkan sebuah hukum yang tidak menimbulkan ambigiutas dalam masyarakat terutama kalangan yang awam dalam persoalan-persoalan jzz'i >Mazhab - mazhab hukum Islam selama telah memproduk beberapa hasil ijtihad dan ini merupakan bagian dari kelunturan hukum untuk merespon kebutuhan zaman. Namun pada bagian lain, ada beberapa hal yang luput dari perhatian ahli hukum terutama pada tataran aplikatif. Artinya fuqahastidak memberikan keterangan yang memadai bagi masyarakat (baca: awam) bagaimana untuk memilih dan memilah keberagaman ini.

Sebagai contoh, masyarakat selama ini kadang-kadang mengamalkan hadith dą'if dan meninggalkan hadith yang lebih kuat karena persoalan yang disebut dengan talfiq (Eklektisisme Mazhab). Talfiq merupakan pengambilan sebagian dari akumulasi pendapat satu mazhab dan kemudian mencampurkan dengan mazhab lain. Pengambilan pendapat (eklektis) ini tentu banyak motifnya, ada karena validitas dalil, rasionalitas argumentasi, kepentingan dan kemaslahatan pribadi dan kelompok (individual dan gaup interest) dan

\footnotetext{
${ }^{19}$ Ibrahim Hosen, "Taqlid dan Ijtihad", dalam Budhy Munawar Rahman, Kontekstualisas Ajaran Isamdalam Sejarah(Jakarta: Yayasan Paramadina, 2009), 4.

${ }^{20}$ Butti Suultan Ali al-Muhairi, IsamisationandModamisationwithinUEA (Penal Law: Shari'ah di Era Modern, Arab Law Quarterly.

${ }^{21}$ Brigit Krawietz, "Cut and Paste in Legal Rule: D isigning Islamic with Talfię", DieWdt desIdam(Leaden Brill, 2002), 42.
} 
seterusnya.

Bila mazhab Shafi'iłah menyebutkan bahwa menyentuh isteri itu tanpa ada satr (penghalang) itu dianggap membatalkan wud \& $>$ sementara mazhab Hanafiyah tidak mengganggap hal itu batal, maka seorang penganut Shafi'iłah tidak boleh kemudian meninggalkan pendapat mazhabnya dan pindah ke mazhab Hanafiæah dan kemudian sqlat kembali lagi kepada mazhab Shafi'i> Ini dianggap telah melakukan talfiø

Padahal orang tersebut telah membaca beberapa hadith terutama tentang słallat Nabi saw di rumahnya lalu beliau bersentuh dengan 'Aisyah. Beliau saw tidak mengulangi wud g' namun tetap melanjutkan słalat. Pendapat ini menurutnya kuat dengan merujuk beberapa referensi.

Di satu sisi, dia sudah diikat dengan mazhab tertentu dan di sisi yang lain adalah dia akan mengabaikan sunnah untuk sebuah mazhab. Konsekuensinya adalah bila dia tinggalkan mazhab, maka mengakibatkan ibadahnya tidak diterima menurut teori talfic sebaliknya dia akan meninggalkan sunnah yang sariby Akhirnya orang tersebut berada dalam posisi yang serba salah. Kondisi real dalam kehidupan masyarakat muslim terutama yang mazhab stream sangat kuat sering dijumpai hal semacam itu.

Bila dilihat dari literatur fiqih sebagaimana disebutkan di atas dalam kaitannya dengan talfiqmaka dapat dikerucutkan kepada beberapa pendapat. Pendapat pertama yang ekstrim mengatakan: tidak ada jalan seseorang untuk berpindah mazhab. Dalam pandangan ini, pindah mazhab itu "mungkin" hampir dekat dengan pindah agama. Pandangan kedua, mereka yang tidak mentolerir talfiq mazhab dalam satu paket ibadah, sementara bila paket yang berbeda itu tidak diperbolehkan. Sementara pandangan ketiga, yang terakhir, mereka yang tidak menghiraukan mazhab dan mengamalkan apa yang dipahami dan dipelajari sesuai dengan keyakinan akan validitasnya.

\section{Penutup}

Talfiq termasuk masalah yang muncul di kemudian hari setelah masa Rasullah s aw dan sahabatnya. Sebagai terma yang tidak dikenal masa awal pembinaan hukum Islam, muslim sebaiknya berlapang dada dalam menerima kenyataan akhir-akhir ini dengan problematika multi-dimensi yang senantiasa terus muncul. Persoalan beragam ini tentu membutuhkan jawaban cepat dan tepat yang tidak mungkin tanpa melakukan proses eklektisisme pemahaman hukum.

Ruh zaman kini tentu tidak memungkinkan perwujudan model hukum dengan mempertahankna status quo terhadap aliran pemikiran tertentu. Alasannya adalah berpikir seperti tidak hanya menaifkan jawaban terhadap problematika yang dihadapi umat, tetapi menimbulkan kerancuan metodologis yang berakhri pada kebuntuan.

\section{Daftar Rujukan}

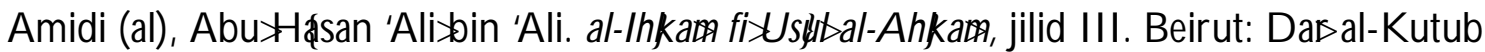
al-'Ilmiyyah, t.th.

Arikunto, Suharsimi. Prosedur Penditian Suatu Pendkkatan Praktek. Jakarta: Rineka Cipta, 1993. Azra, Azyumardi dkk. Ensikloped Islam Jakarta: Ichtiar Baru van Hoeve, 2005.

Bani (al), Muhammad Sa'id. Undat al-Tahłiq fi al-Taqlid wa al-Talfiq. Beirut: al-Maktab al- 
Islami> 1981.

D ahlan, Abdul Azis (dkk.). Ensiklqped HukumIdam Jakarta: Ichtiar Baru van Hoeve, 1997. G hazali (al), A bu<H Munawwarah li al-Tab' wa al-Nashr, t.th.

Hosen, Ibrahim. "Taqlid dan Ijtihad", dalam Budhy Munawar-Rachman, Kontksstualisas Ddktrin Isam dalam Sgarah Jakarta: Yayasan Paramadina, 2009.

Ibn Taimiyyah. Majmú al-Fatana>sjlid XX. Beirut: D as 'Alam al-Kutub, 1991. Jawzi (al), Ibn al-Q ayyim. Ilamal-Mumaqpiin, Jilid IV.

Krawietz, Brigit. "Cut and Paste in Legal Rules: D esigning Islamic with Talfiø", DieWdt des Isam Leide: Brill, 2002.

Muhairi (al), Butti Sultan Butti Ali. Isamisation dan Modkmisation vithin UEA Penal Law: shariah di Modern Era, 1995, ArabLawQuartely.

Mursyid, G haziłbin. Talfiq bayn al-Madhakib al-Fiqhiyah wa 'Alaqah bi Taysir al-Fatwa`Mekkah: Jami'ah Umm al-Qurra' Press, 2009.

Muti'i (al), Muhammad Bukhait. Sullamal-Wuskllili Sharh Nihayat al-Şal , Jild 4. Beirut: 'Alam al-Kutub, t.th.

Nabulsi (al), Abd al-G hani> al-Tahфiq fi`Bayan Hxkm al-Taqid wa al-Talfiq Beirut: D as alFikr, t.th.

Q urtubiłal), Muhammad Ibn Rushd. Bidayat al-Mujtahid, Jilid I. Beirut: D as al-Ma'rifah, t.th. Q aradł̧wi>(al), Yusuf. Taysir al-Fiqh li al-Musimal-Múasir. Mesir: Maktabah Wahbah, 1999. Saffarini (al), Muhammad bin A hmad. al-Tahłiqfi Butlanal-Talfiø. Mesir: D aæal-Sami'i, 1998. Umar, M. Hasbi. Nalar Fiqh Konterpare. Jakarta: G aung Persada, 2007.

Zarkashiłal), Muhammad bin Bahadir. Al-Bahral-Muhilyfi UsłllbFiqh Jilid VI. Kuwait: Wizakat al-Awqaf al-Kuwaitiyah, 1992.

Zaybari (al), 'Amir bin Sa'id. Mabakith fiðhkamal-Fatva. Beirut: Daæ Ibn Hazm, 1995. 